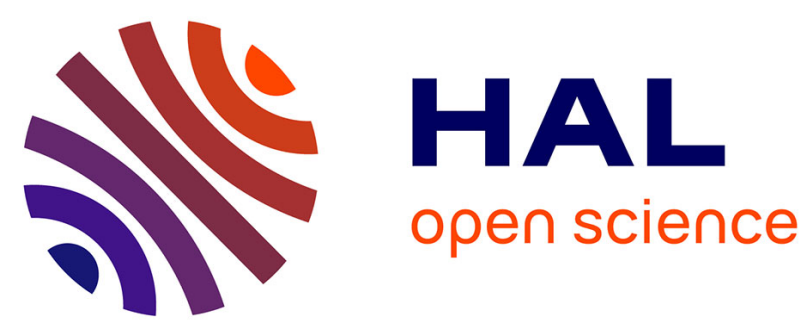

\title{
Longitudinal predictors of bronchial hyperresponsiveness and FEV1 decline in bakers
}

Valérie Demange, Michel Grzebyk, Michel Hery, Nicole Massin, Christophe Paris, Pascal Wild

\section{- To cite this version:}

Valérie Demange, Michel Grzebyk, Michel Hery, Nicole Massin, Christophe Paris, et al.. Longitudinal predictors of bronchial hyperresponsiveness and FEV1 decline in bakers. International Archives of Occupational and Environmental Health, 2021, 94 (4), pp.751-761. 10.1007/s00420-020-01628-0 . hal-03131173

\section{HAL Id: hal-03131173 \\ https://hal.science/hal-03131173}

Submitted on 23 Mar 2021

HAL is a multi-disciplinary open access archive for the deposit and dissemination of scientific research documents, whether they are published or not. The documents may come from teaching and research institutions in France or abroad, or from public or private research centers.
L'archive ouverte pluridisciplinaire HAL, est destinée au dépôt et à la diffusion de documents scientifiques de niveau recherche, publiés ou non, émanant des établissements d'enseignement et de recherche français ou étrangers, des laboratoires publics ou privés. 
Longitudinal predictors of bronchial hyperresponsiveness and FEV 1 decline in bakers

Valérie Demange ${ }^{1}$, Michel Grzebyk ${ }^{1}$, Michel Héry ${ }^{1}$, Nicole Massin ${ }^{1}$, Christophe Paris ${ }^{2,3}$, Pascal Wild ${ }^{1}$.

1 Institut National de Recherche et de Sécurité (INRS), Vandœuvre les Nancy, France

2 CHU de Rennes, Rennes, France

3 INSERM U1085-IRSET, Rennes, France

Corresponding author: Valérie Demange valerie.demange@inrs.fr. 0000-0003-2945-2564

Michel Grzebyk 0000-0001-6522-7554

Michel Héry 0000-0002-2758-4873

Chris tophe Paris 0000-0001-6417-4980

Pascal Wild 0000-0003-3165-3808

\section{Acknowledgments}

The authors are grateful to all workers who participated in the study. They thank all company directors, managers and occupationalphysicians who were involved. They also thank Régis Colin from INRS for his precious help in the data management. 


\section{ABSTRACT}

Objective: To determine long-term predictors of bronchial hyperresponsiveness (BHR) and forced expiratory volume in one second $\left(\mathrm{FEV}_{1}\right)$ decline.

Methods: A longitudinal study in 110 bakers in 4 industrial bakeries and 38 non-exposed workers was conducted at the workplace with a mean of 3.3 visits per subject over a period of 13 years and a mean duration of follow-up of 6 years in bakers and 8 years in non-exposed subjects. A respiratory health questionnaire was administered; occupational allergen skin prick tests, spirometry and a methacholine bronchial challenge test were performed at each visit. In each bakery, full-shift dust samples of the inhalable fraction were obtained in order to assess the exposure of each job assignment. The repeated measurements of $\mathrm{BHR}$ and $\mathrm{FEV}_{1}$ were analyzed using mixed effects logistic and linear regression models in subjects seen at least twice.

Results: BHR, respiratory symptoms and their simultaneous occurrence depended on the duration of exposure. $\mathrm{FEV}_{1}$ significantly decreased with duration of exposure and BHR at a preceding visit. This result persisted when adjusting for the effect of BHR at the current visit. The measured exposure levels were not a significant predictor for any outcome. Occupational sensitization was only a predictor of a decline in $\mathrm{FEV}_{1}$ when duration of exposure was not included.

Conclusion: In flour-exposed industrial bakers, length of exposure and smoking are long-term determinants of BHR and of the decrease in $\mathrm{FEV}_{1}$. BHR at a preceding visit predicted lower $\mathrm{FEV}_{1}$ even when accounting for the effect of BHR at the current visit.

Keywords: epidemiology - longitudinal study - bakers - occupational exposure - bronchial hyperresponsiveness lung function 


\section{INTRODUCTION}

Baker's asthma is one of the most frequent occupational asthma (OA) in industrialized countries (Jeebhay et al. 2019; Page et al. 2010). The prevalence is estimated to be from 4 to $13 \%$ (Jeebhay et al. 2019). In France, flour was still the most frequent causative agent of OA during the period 2008-2014 (Iwatsubo et al. 2016). Baker's asthma has seen the list of its causative agents expand over the years with the evolution of baking techniques, with the use of cereal flour, fungal enzymes, other ingredients like white egg proteins but also the presence of storage mites, arthropods, and molds (Quirce and Diaz-Perales 2013).

Bronchial hyperresponsiveness (BHR) is considered the physiological hallmark of asthma, whether occupational or not (Malo et al. 2015) (Lipinska-Ojrzanowska et al. 2020). Thus, it is a common hypothes is that BHR is a stage on the pathway to asthma (Malo et al. 2015; Radon et al. 2016). A longitudinal follow up of the BHR status in populations exposed to asthmogens seems therefore to be relevant.

Apart in asthma, BHR is also observed in other lung diseases, such as chronic obstructive pulmonary disease (Borak and Lefkowitz 2016). BHR was shown to be a predictor of irreversible loss of lung function in asthmatics with or without pulmonary symptoms (Borak and Lefkowitz 2016), but also in asymptomatic individuals from a Swiss population-based cohort (Brutsche et al. 2006) and in followed-up firefighters (Aldrich et al. 2016). However, BHR was not predictive of lung function loss in a recent relatively short-term study among aluminium smelter workers (Abramson et al. 2020).

An association of occupational flour dust exposure with a decreased lung function has been found in flour mill (Bagheri et al. 2013; Demeke and Haile 2018; Lagiso et al. 2020; Mohammadien et al. 2013; Zamani et al. 2019) or bakery workers (Fahim and El-Prince 2013; Moghaddasiet al. 2014; Said et al. 2017), as recently reviewed by Zamani (Zamani et al. 2019). In these studies, the occupational flour dust exposure was solely represented by the exposure status (Fahim and El-Prince 2013; Lagiso et al. 2020; Moghaddasi et al. 2014; Mohammadien et al. 2013), the duration of exposure (Demeke and Haile 2018; Said et al. 2017), or by the atmospheric flour dust concentration at the time of the data collection (Bagheri et al. 2013; Zamani et al. 2019). Different spirometric parameters were affected depending on the study (Zamani et al. 2019). All these studies were cross sectional, with the exception of the two-year follow-up study by Zamani et al. Indeed, many of the published longitudinal studies in bakers concerned rather apprentices (Acouetey et al. 2013; de Meer et al. 2003; De Zotti and Bovenzi 2000; Demange et al. 2018; Gautrin et al. 2000; Skjold et al. 2008; Tossa et al. 2010; Walusiak et al. 2002). These studies 
brought knowledge about the time course of the work-related respiratory symptoms or diseases at the beginning of exposure. The highest incidence of these symptoms seems to be in the first 6 to 12 months of employment (Radon et al. 2016). The recognised risk factors are atopy (Skjold et al. 2008), pre-existing sensitization to occupational allergens, (de Meer et al. 2003) and BHR (de Meer et al. 2003; Demange et al. 2018; Radon et al. 2016; Skjold et al. 2008). We identified four longitudinal studies in bakers at work (Cullinan et al. 2001; Florentin et al. 2014; Kim et al. 2013; Remen et al. 2013). None of these studies were focused on BHR and lung function evolution, except for Kim et al., who focused on BHR changes after 6 month job relocation in a small population of 12 bakers.

The present longitudinal study aimed at describing the natural history of BHR and FEV1 decline by identifying their respective predictors, in a population of bakers and a group of non-exposed controls, the latter providing a baseline for the exploration of the dose-response relationships

\section{MATERIALS AND METHODS}

\section{Study design and inclusion criteria}

The study design was a longitudinal follow-up of the workforces at 4 industrial bakeries, with visits in 1992, 1994, 1996, 2001, 2003 and $2005(n=110)$ and of a non-exposed group of blue-collar workers $(n=38)$ at a salt-packing factory with visits in 1993, 2002, 2004 and 2006. Each visit comprised a clinical examination, a standardized respiratory questionnaire, occupational allergen skin prick tests (SPT), pulmonary function tests and a methacholine bronchial challenge test, all carried out at the workplace. The cross-sectionalanalysis of the initial data collected in 1992 was previously published (Bohadana et al. 1994). The baker jobs were croissant making, dough mixing, special breads making, general bread making, control and packaging, deliveries, cleaning, oven handling. The non-exposed salt-packing factory workers were employed in production, maintenance, or quality control departments. All workers who volunteered to participate were included. However, workers with an acute respiratory infection were not included in the visit. The non-exposed subjects were included if they had not been occupationally exposed to flour dusts or to another respiratory health hazard. As the aim of this paper was to determine long-term predictors, we included in the analyses all subjects who had attended at least two visits. Figure 1 presents the flowchart of the participation of the subjects in the study. 


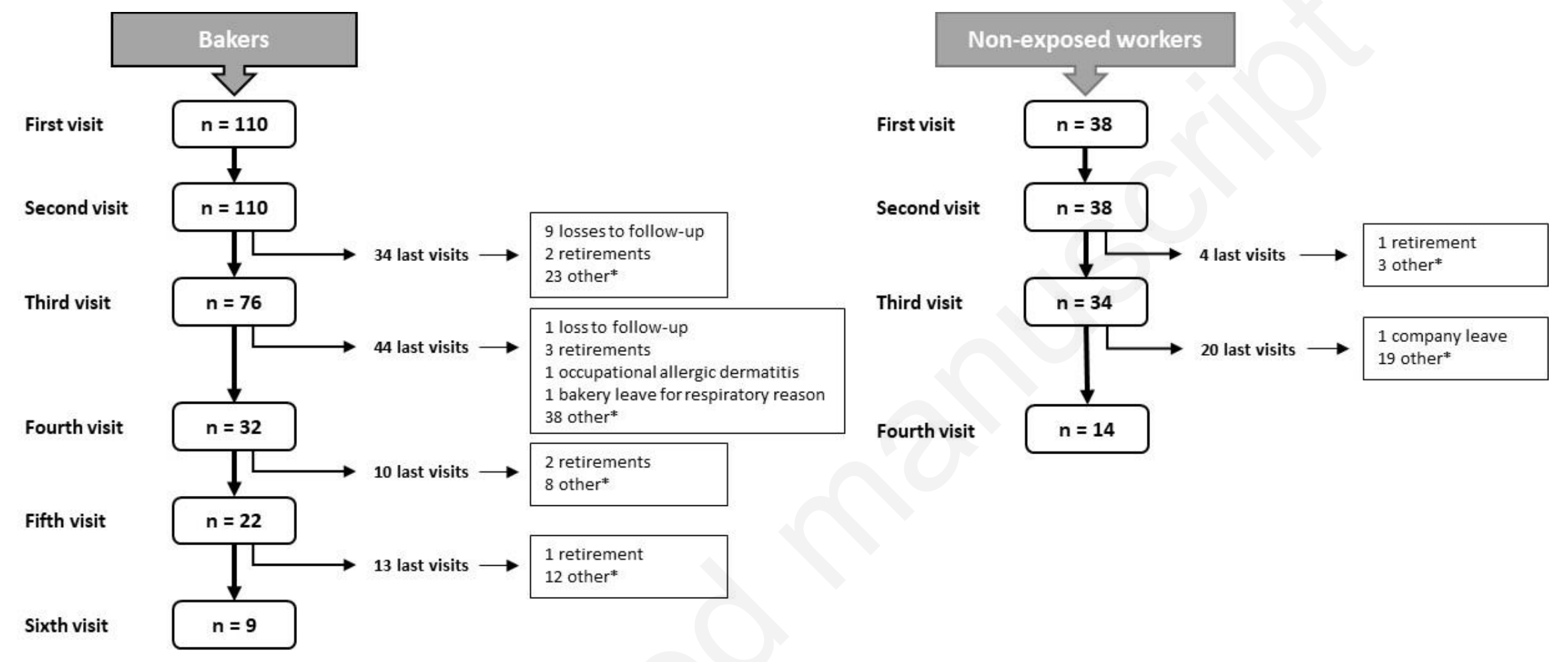

Figure 1 Flow chart of the study. *drop-out unrelated to health 


\section{Respiratory health status}

Respiratory symptoms were recorded at each medical examination by the same experienced interviewer using the European Coal and Steel Community questionnaire (Bohadana et al. 1994; Minette 1989). The questionnaire included detailed smoking habits, history of respiratory diseases and childhood allergic disea ses such as asthma and eczema. Clinical atopy was defined as having childhood allergic diseases (asthma or eczema). At each visit, we abstracted respiratory symptoms defined as a wheezing chest or a runny nose in absence of any cold.

Spirometry was carried out by the same 3 experienced technicians using the same electronic spirometer (Spiro Analyzer ST 300, Fukuda Sangyo Co. Tokyo, Japan) in compliance with the European Respiratory Society recommendations (Quanjer et al. 1993). The observed/predicted $\mathrm{FEV}_{1}$ ratio was used for description, using the reference equations from Quanjer (Quanjer et al. 1993).

We used 3 additive doses of methacholine delivered by a nebulizer (Mediprom FDC 88 - Paris, France), according to an abbreviated version of the methacholine bronchial challenge (MBC) test (Gardner 1979). This corresponds to a maximal inhalated dose of $11.5 \mu \mathrm{mol}$, i.e. $2100 \mu \mathrm{g}$. The first dose of $0.5 \mu \mathrm{mol}$ is equivalent to one puff from an aerosolized solution with a concentration of $0.36 \mathrm{mg} / \mathrm{ml}$, using a nebulizer delivering $0.14 \mathrm{ml} / \mathrm{minute}$ during 2 minutes. The second dose of $2.5 \mu \mathrm{mol}$ is equivalent to one puff from an aerosolized solution with a concentration of $1.79 \mathrm{mg} / \mathrm{ml}$. The third and final dose of $7.5 \mu \mathrm{mol}$ is equivalent to one puff from an aerosolized solution with a concentration of $5.36 \mathrm{mg} / \mathrm{ml}$

The challenge test was discontinued either after the inhalation of the last dose of methacholine or if the FEV $\mathrm{fell}_{1}$ by $20 \%$ or more below the baseline value obtained prior to MBC testing. In that case, subjects were classified as having a positive $\mathrm{MBC}$ test, i.e. having bronchial hyperresponsiveness (denoted BHR in the sequel).

\section{Skin prick tests to occupational allergens}

Three SPTs were performed using wheat flour, rye flour and alpha amylase respectively (Stallergenes Laboratories, Fresnes, France). A 9\% codeine phosphate solution was used as a positive control and the $50 \%$ glycerinated diluent as a negative control. A positive SPT was defined as a wheal diameter at least $3 \mathrm{~mm}$ larger than those obtained with the negative controls after 20 minutes. Sensitization to occupational allergens was defined at each visit as a positive reaction to at least one of the three allergens tested.

\section{Exposure assessment}

In each bakery, some full-shift dust samples of the inhalable fraction were obtained in order to assess the exposure of each job assignment. Closed-face filter holders were used (Millipore, Massachusetts, USA), housing pre- 
weighed 37-mm diameter polyvinyl chloride filters (Pall Gelman Sciences, Champs sur Marne), connected to portable battery-operated vacuum pumps (Escort, MSA, Châtillon sur Chalaronne) sampling at airflow rates of 1 $1 / \mathrm{mn}$. The PVC filters were weighed twice: in the laboratory during their preparation before sampling, and again in the same laboratory after sampling. These weighings were done in a controlled and constant atmosphere for heat and humidity, after a stay of at least twelve hours in the room. Before the first weighing, the filters were treated with Triton to eliminate electrostatic charges. The pumps were calibrated before and after sampling. Generally, the samples were taken on workers, with the filter holder fixed near the breathing zone. In exceptional cases stationary sampling was used: for team leaders in charge of administrative tasks in a room isolated from the workshop. They were reserved for workers present in this room in a static position and who did not intervene directly in the manufacturing process. The pumps and sample holders were placed a few tens of centimeters away from their upper respiratory tracts. This measurement of the airborne exposure could thus be considered as repres entative of their individual exposure.

For a given job, the exposure level was calculated as the mean value of the dust concentration measurements obtained for this job. As these measurements could not be considered an exact measurement of the chronic exposure, these exposure means were categorized into three groups, $<1 \mathrm{mg} / \mathrm{m} 3,1-5 \mathrm{mg} / \mathrm{m} 3,>5 \mathrm{mg} / \mathrm{m} 3$ which were considered reliable by the experienced industrial hygienist $(\mathrm{MH})$ who was part of the research group. This exposure level was assigned to all workers of the job. Exposure measurements were repeated several times over the entire study period, at least each time the working conditions (new equipment, automation of a production line, etc.) changed.

\section{Statistics}

According to the main objective of this study, we studied the respective determinants of BHR and respiratory symptoms, and the determinants of the evolution of $\mathrm{FEV}_{1}$ during the study follow-up.

Firstly, we studied whether BHR, respiratory symptoms and their joint occurrence were associated with gender, cumulative smoking, clinical atopy, sensitization to occupational allergens and exposure to flour dust (level and duration) using a mixed logistic regression with the subject as a random factor to account for the longitudinal nature of the data. Secondly, the repeated $\mathrm{FEV}_{1}$ measurements were modelled using linear mixed models with the subject as random effect. Several models were considered, including cumulative smoking, pre-visit and concurrent BHR, sensitization to occupationalallergens, duration and exposure level, as independent variables. All analyses 
were adjusted for the technician performing the spirometry. Age, gender and height were taken into account by subtracting the predicted $\mathrm{FEV}_{1}$ from the observed values.

The analysis was carried out with STATA statistical software (STATA, College Station, TX, USA).

\section{RESULTS}

One hundred and ten bakers and 38 non-exposed subjects attended the inclusion visit and at least one follow-up visit, representing 483 visits. That is 3.3 visits per subject with a mean duration of follow-up of 6 years among the bakers and 8 years among the non-exposed subjects. Table 1 gives a basic description of subjects at inclusion, from inclusion to last follow-up, and at the last visit. At inclusion, clinical atopy was less often reported by bakers (11\%) than non-exposed workers $(21 \%)$, whereas sensitization to occupationalallergens was more often observed in bakers $(20 \%$ versus $16 \%)$. At the last visit, this prevalence was $30 \%$ in bakers versus $10 \%$ in non-exposed workers. At inclusion, the exposed workers had been working as bakers for 10.6 years on average and the most frequent category of exposure level to inhalable dust was between 1 to $5 \mathrm{mg} / \mathrm{m}^{3}$ at inclusion and at the last visit. 
Table 1. Basic description of population study

\begin{tabular}{|c|c|c|}
\hline & Exposed subjects & Non-exposed \\
\hline $\mathrm{n}(\%)$ & $110(74.3 \%)$ & $38(25.7 \%)$ \\
\hline Women $\mathrm{n}(\%$ in column $)$ & $16(14.5 \%)$ & $2(5.3 \%)$ \\
\hline Men $\mathrm{n}(\%$ in column $)$ & $94(85.4 \%)$ & $36(94.7 \%)$ \\
\hline \multicolumn{3}{|l|}{ At inclusion } \\
\hline Age in years, mean (SD) $\min -\max$ & 36.7 (10.8) 19-59 & $41.7(6.5) \quad 27-51$ \\
\hline Duration of past exposure in years, mean (SD) $\min -\max$ & $10.6(7.8) \quad 0.01-32.0$ & - \\
\hline Clinical atopy, $\mathrm{n}(\%)$ & $12(10.9 \%)$ & $8(21.0 \%)$ \\
\hline At least one sensitization to occupational allergens & $22(20.2 \%)$ & $3(15.8 \%)$ \\
\hline Mis sing data, $\mathrm{n}(\%)$ & $1(0.9 \%)$ & $19(50.0 \%)$ \\
\hline Sensitization to wheat & $16(14.7 \%)$ & $1(5.3 \%)$ \\
\hline Sensitization to rye & $10(16.1 \%)$ & $2(10.5 \%)$ \\
\hline Sensitization to alpha amylase & $2(3.6 \%)$ & - \\
\hline \multicolumn{3}{|l|}{...Exposure level ${ }^{\mathrm{a}}$ in $\mathrm{mg} / \mathrm{m}^{3}, \mathrm{n}(\%)$} \\
\hline$\ldots<1, \mathrm{n}(\%)$ & $27(24.5 \%)$ & - \\
\hline$\ldots 1-5, \mathrm{n}(\%)$ & $74(67.3 \%)$ & - \\
\hline$\ldots>5, \mathrm{n}(\%)$ & $9(8.2 \%)$ & - \\
\hline \multicolumn{3}{|l|}{ Smoking status } \\
\hline Non-smoker, $\mathrm{n}$ (\% in column) & $42(38.2 \%)$ & $13(34.2 \%)$ \\
\hline Current smoker, $\mathrm{n}$ (\% in column) & $52(47.3 \%)$ & $15(39.5 \%)$ \\
\hline Pack-years of cigarettes, mean (SD) & $14.8(13.5)$ & $21.8(15.3)$ \\
\hline Ex-smoker, $\mathrm{n}(\%$ in column $)$ & $16(14.5 \%)$ & $10(26.3 \%)$ \\
\hline Pack-years of cigarettes, mean (SD) & $20.5(16.5)$ & $11.3(9.3)$ \\
\hline \multicolumn{3}{|l|}{ From inclusion to last follow-up } \\
\hline Total duration in years, mean (SD) & 5.7 (3.5) $1.0-12.8$ & $8.1(4.5)$ 2.6-12.9 \\
\hline \multicolumn{3}{|l|}{$\mathrm{Nb}$ visits per subject, mean (SD) $\min -\max$} \\
\hline At exposure level $<1$ & $0.7(1.2) 0-5$ & - \\
\hline At exposure level 1-5 & $2.2(1.4) 0-6$ & - \\
\hline At exposure level $>5$ & $0.3(0.8) 0-3$ & - \\
\hline Total & $3.3(1.2) 2-6$ & $3.3(0.6) 2-4$ \\
\hline At last follow-up visit (n (\%)) & $110(74.3 \%)$ & $38(25.7 \%)$ \\
\hline Age in years, mean (SD) $\min -\max$ & 42.4 (10.5) 22-61 & $49.8(6.7) \quad 33-59$ \\
\hline At least one sensitization to occupational allergens & $33(30.0 \%)$ & $4(10.5 \%)$ \\
\hline Missing data, $\mathrm{n}(\%)$ & 0 & 0 \\
\hline Sensitization to wheat & $10(10.5 \%)$ & - \\
\hline Sensitization to rye & $15(16.3 \%)$ & - \\
\hline Sensitization to alpha amylase & $5(11.6 \%)$ & - \\
\hline \multicolumn{3}{|l|}{ Exposure level ${ }^{\mathrm{a}}$ in $\mathrm{mg} / \mathrm{m}^{3}, \mathrm{n}(\%)$} \\
\hline$\ldots<1, \mathrm{n}(\%)$ & $25(22.7 \%)$ & - \\
\hline$\ldots 1-5, \mathrm{n}(\%)$ & $79(71.8 \%)$ & - \\
\hline$\ldots>5, \mathrm{n}(\%)$ & $6(5.5 \%)$ & - \\
\hline \multicolumn{3}{|l|}{ Smoking status } \\
\hline Non-smoker, $\mathrm{n}$ (\% in column) & $40(36.4 \%)$ & $13(34.2 \%)$ \\
\hline Current smoker, $\mathrm{n}(\%$ in column $)$ & $45(40.9 \%)$ & $7(18.4 \%)$ \\
\hline
\end{tabular}


Pack-years of cigarettes, mean (SD

$19.2(14.2)$

32.7 (23.2)

Ex-smoker, $\mathrm{n}(\%$ in column $)$

a: defined as the average of the inhalable dust concentrations for the different jobs held by the worker

Table 2 describes the health outcomes of interest according to the exposure status, at inclusion and the last visit. At inclusion, the prevalence of BHR was $24 \%$ in bakers and increased to reach $36 \%$ at the last visit. In non -exposed workers, this prevalence increased slightly between these two visits ( 8 and 11\%, respectively). Moreover, in bakers at both visits, the prevalence of BHR increased with duration of exposure. Such a pattern was not observed with the exposure level. The prevalence of respiratory symptoms was similar at inclusion in exposed and non-exposed workers (38\% versus $34 \%$, respectively), while it was higher in bakers at the last visit $(52 \%$ versus $40 \%$, respectively). For this outcome, no pattern with duration of exposure or mean level of exposure was observed. The observed $\mathrm{FEV}_{1}$ was close to the predicted value in bakers both at inclusion and the last visit, and slightly higher in non-exposed workers. In bakers, at both visits, the $\mathrm{FEV}_{1}$ in percent predicted decreased with duration of exposure. As for BHR prevalence, no pattern was observed with the exposure level. 
Table 2. Description of the health outcomes

\begin{tabular}{|c|c|c|c|c|}
\hline & $\begin{array}{l}\text { Bronchial } \\
\text { hyperresponsiveness }^{\mathrm{a}}\end{array}$ & $\begin{array}{l}\text { Respiratory } \\
\text { symptoms }^{b}\end{array}$ & $\begin{array}{l}\mathrm{FEV}_{1} \text { in } \% \text { predicted }^{\mathrm{c}} \\
\text { (mean [SD]) }\end{array}$ & Total \\
\hline \multicolumn{5}{|l|}{ At inclusion } \\
\hline Non-exposed workers & $3(7.9 \%)$ & $13(34.2 \%)$ & $104.5[15.0]$ & 38 \\
\hline Missing data & $2(5.3 \%)$ & 0 & 0 & \\
\hline Exposed workers & $26(23.6 \%)$ & $42(38.2 \%)$ & $99.6[13.8]$ & 110 \\
\hline \multicolumn{5}{|c|}{ Exposure level $\left(\mathrm{mg} / \mathrm{m}^{3}\right)$} \\
\hline Missing data & $4(3.6 \%)$ & 0 & 0 & \\
\hline$<1$ & $5(18.5 \%)$ & $5(18.5 \%)$ & $95.6[15.9]$ & 27 \\
\hline$[1-5]$ & $19(25.7 \%)$ & $36(48.7 \%)$ & $101.1[13.3]$ & 74 \\
\hline$>5$ & $2(22.2 \%)$ & $1(11.1 \%)$ & 99.7 [9.9] & 9 \\
\hline \multicolumn{5}{|c|}{ Duration of exposure (years) } \\
\hline$<10$ & $10(18.9 \%)$ & $19(35.9 \%)$ & $101.5[12.3]$ & 53 \\
\hline$[10-20]$ & $8(19.5 \%)$ & $14(34.1 \%)$ & $100.2[15.1]$ & 41 \\
\hline$>20$ & $8(50.0 \%)$ & $9(56.2 \%)$ & $91.9[13.3]$ & 16 \\
\hline \multicolumn{5}{|l|}{ At the last visit } \\
\hline Non-exposed workers & $4(10.5 \%)$ & $15(39.5 \%)$ & $101.5[14.9]$ & 38 \\
\hline Missing data & $5(13.2 \%)$ & 0 & $1(2.6 \%)$ & \\
\hline Exposed workers & $40(36.4 \%)$ & $57(51.8 \%)$ & $99.8[15.7]$ & 110 \\
\hline \multicolumn{5}{|c|}{ Exposure level $\left(\mathrm{mg} / \mathrm{m}^{3}\right)$} \\
\hline Missing data & 0 & 0 & 0 & \\
\hline$<1$ & $11(44.0 \%)$ & $12(48.0 \%)$ & $101.9[19.0]$ & 25 \\
\hline$[1-5]$ & $27(34.2 \%)$ & $44(55.7 \%)$ & $99.2[15.0]$ & 79 \\
\hline$>5$ & $2(33.3 \%)$ & $1(16.7 \%)$ & $98.6[11.7]$ & 6 \\
\hline \multicolumn{5}{|c|}{ Duration of exposure (years) } \\
\hline$<10$ & $10(31.2 \%)$ & $16(50.0 \%)$ & $104.7[13.0]$ & 32 \\
\hline [10-20] & $13(32.5 \%)$ & $21(52.5 \%)$ & $101.5[15.4]$ & 40 \\
\hline$>20$ & $17(44.7 \%)$ & $20(52.6 \%)$ & $93.9[16.6]$ & 38 \\
\hline
\end{tabular}

a: defined as fall in $\mathrm{FEV}_{1}$ of $20 \%$ or more during the MBC test; ${ }^{\mathrm{b}}$ : defined as a wheezing chest or a runny nose in absence of any cold; ${ }^{c}$ : observed / predicted $\mathrm{FEV}_{1}$ ratio using the reference equations from Quanjer (1993). 
The probability of having BHR (Table 3) doubled when the duration of exposure increased by ten years (adjusted $\mathrm{OR}=2.2,95 \% \mathrm{CI}=[1.0 ; 5.0])$. Female gender and the number of pack-years for ever-smokers also significantly increased the probability of having BHR. The probability of reporting respiratory symptoms was multiplied by almost 4 when the duration of exposure increased by ten years (adjusted $\mathrm{OR}=3.6,95 \% \mathrm{CI}=[1.4 ; 9.4]$ ). Clinical atopy was significantly associated with respiratory symptoms (adjusted $\mathrm{OR}=16.5,95 \% \mathrm{CI}=[1.7 ; 157.1]$ ). When considering having BHR and at least one respiratory symptom simultaneously, duration of exposure and clinical atopy were significant predictors. The exposure level had no statistical significant effect on any of the three outcomes considered, neither did a history of sensitization to occupational allergens. 
Table 3. Models for the health outcomes according to a mixed logistic regression (OR $[95 \% \mathrm{CI}]$ )

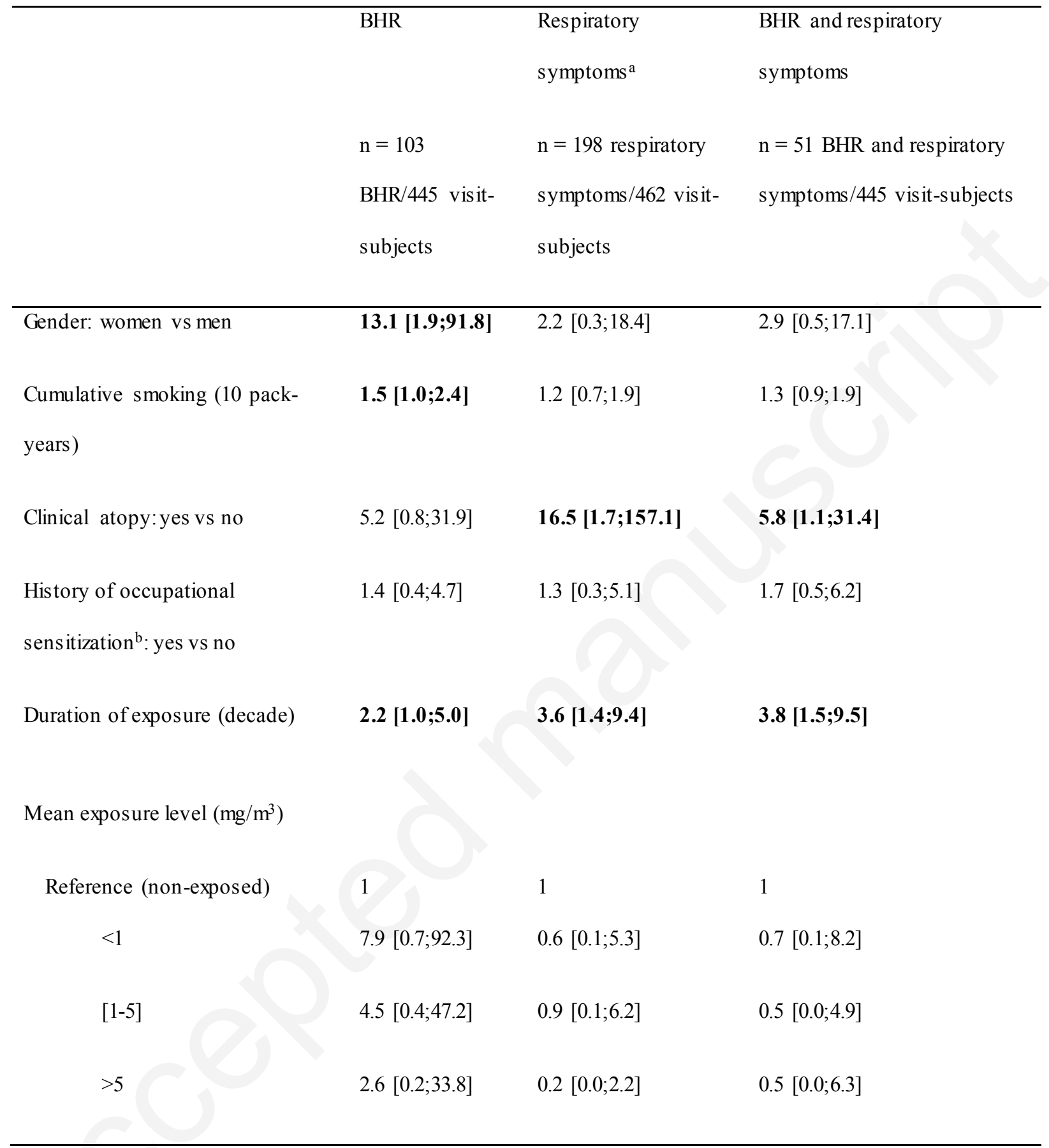

BHR : bronchial hyperresponsiveness defined as fall in $\mathrm{FEV}_{1}$ of $20 \%$ or more during the MBC test

a: respiratory symptoms defined as a wheezing chest or a runny nose in absence of any cold

b: sensitization to occupational allergens at least once during follow-up 
Table 4 presents the results of two multiple linear regression analyses of $\triangle \mathrm{FEV}_{1}$, the difference between observed $\mathrm{FEV}_{1}$ and its predicted value (Quanjer et al. 1993) according to gender, height and age. In the first model, $\Delta \mathrm{FEV}$ decreased by almost $200 \mathrm{ml}$ per ten years of exposure (adjusted $\beta=-193.5,95 \% \mathrm{CI}=[-268.0 ;-119.1]$ ). BHR at a preceding visit was significantly (although borderline) associated with $\triangle \mathrm{FEV}_{1}$ even after adjustment for the significant effect of BHR at the current visit. Similarly to the results for symptoms and BHR, there was no effect of the exposure level. Finally, as expected, $\triangle \mathrm{FEV}_{1}$ decreased significantly with smoking (by $6 \mathrm{ml}$ per pack year). The second model excluding the (non-significant) exposure level and including the history of occupational sensitization confirmed the relationship with duration of exposure, the association with BHR at the current visit and cumulative smoking. Having had BHR at a preceding visit was now borderline non-significant. A history of occupational sensitization had no statistically significant effect on $\triangle F E V_{1}$. However, when excluding duration of exposure, history of occupational sensitization predicted a statistically significant decrease of $\Delta \mathrm{FEV}_{1}$ (data not shown). For all outcomes, we tested interactions between the different independent variables. None was statistically significant. 
Table 4. Models for $\triangle F E V 1$ (Observed-predicted according to gender, height and age) in $\mathrm{ml}$ according to a multiple linear mixed analysis $(\beta$ coefficient $[95 \% \mathrm{CI}])$.

\begin{tabular}{|c|c|c|}
\hline & Model 1 & Model 2 \\
\hline & $\mathrm{N}=466$ visits for 146 subjects & $\begin{array}{l}\mathrm{N}=445 \text { visits for } 146 \\
\text { subjects }\end{array}$ \\
\hline Cumulative smoking (10 pack-years) & $-61.8[-111.8,-11.7]$ & $-57.9[-108.3,-7.4]$ \\
\hline Pre-visit BHR: yes vs no & $-81.4[-161.8,-0.1]$ & $-76.5[-154.8,1.8]$ \\
\hline $\begin{array}{l}\text { Having BHR at the current visit: yes } \\
\text { vs no }\end{array}$ & $-95.3[-168.0,-22.7]$ & $-93.6[-163.9,-23.2]$ \\
\hline $\begin{array}{l}\text { History of occupational } \\
\text { sensitization }{ }^{\text {a: }} \text { yes vs no }\end{array}$ & & $-63.2[-165.8,39.4]$ \\
\hline Duration of exposure (decade) & $-193.5[-268.0,-119.1]$ & $-188.2[-254.1,-122.2]$ \\
\hline \multicolumn{3}{|l|}{ Mean exposure level $\left(\mathrm{mg} / \mathrm{m}^{3}\right)$} \\
\hline Reference (non-exposed) & 1 & \\
\hline$<1$ & $96.8[-122.4,316.0]$ & \\
\hline$[1-5]$ & $94.1[-120.4,308.6]$ & \\
\hline$>5$ & $14.8[-74.0,370.7]$ & \\
\hline
\end{tabular}

CI: Confidence Interval

$\beta$ coefficient: multiple linear regression coefficient

BHR: bronchial hyperresponsiveness defined as fall in $\mathrm{FEV}_{1}$ of $20 \%$ or more during the $\mathrm{MBC}$ test

a: sensitization to occupational allergens at least once during follow-up 


\section{DISCUSSION}

In our study, BHR, respiratory symptoms and their simultaneous occurrence depended on duration of exposure, which confirms, for BHR, the cross-sectional results previously published on the inclusion data (Bohadana et al. 1994). Analysing respiratory symptoms, odds ratios for clinical atopy were high and statistically significant. FEV 1 significantly decreased with duration of exposure and BHR at a preceding visit. This result persisted when accounting for the effect of BHR at the current visit. No effect of quantitative exposure level was observed.

In our study, the odds ratio of clinical atopy when analysing BHR was high although not significant. This is consistent with previous analyses of data of a cohort of apprentice bakers and pastry-makers, in which atopy or degree of sensitization was associated with incidence of BHR (Tossa et al. 2010; Wild et al. 2017). Duration of follow-up in that study was shorter (18 months) than in the present study, and study populations were younger (mean age about 18 years) with no previous occupational exposure to flour. A possible explanation of the less clearcut effect of atopy could be that atopy has an effect on BHR in the first years of occupational exposure but no later effect on the onset of BHR. Indeed, the workers in our study had finished their apprenticeships since an average of 11 years at inclusion. However, it is noticeable that the prevalence of atopy was lower among bakers than in non-exposed subjects in our study. This suggests a selection effect with an early drop-out from the job of the subjects with atopy previous to the recruitment into the study. Such an effect was shown earlier in earlier studies among pastry-making or hairdressing apprentices (Iwatsubo et al. 2003; Monso et al. 2000). It could also be a healthy hire effect, by which subjects with childhood allergic diseases avoid high risk occupations, as suggested by results from a British cohort (Butland et al. 2011). As in the Butland study, we used a definition of atopy based on self-reported childhood allergic diseases, which is different from the definition used in the former cited studies (Monso et al. 2000; Tossa et al. 2010; Wild et al. 2017), based on specific IgE or SPT as in the standardized definition. This definition is the recommended one (Johansson et al. 2001), unfortunately we could not perform any of these investigations and used instead a definition based on a questionnaire. However, it has been suggested that a questionnaire may capture a more consistent chronic picture of atopy (Hoppin et al. 2011) than these biochemical measures. Both prevalences of $\operatorname{IgE}$ sensitization or allergen skin test reactivity in (not elderly) adults have been found to decrease over 20 (Amaral et al. 2016) and 10 (Warm et al. 2012) years of followup. However, self-reporting symptoms have other defaults such as recall bias. 
In our study, we failed to observe a statistically significant effect of occupational sensitization on BHR, respiratory symptoms or $\triangle \mathrm{FEV}_{1}$, although in the literature, sensitization to occupationalallergens has been observed to be a risk factor for work-related symptoms in bakers (Droste et al. 2005; Harris-Roberts et al. 2009; Hur et al. 2008; Jacobs et al. 2008; Mbatchou Ngahane et al. 2014; Olivieri et al. 2013) or for exercise-induced bronchoconstriction (Minov et al. 2013). Moreover, high levels of flour-specific IgE have been found to be good predictors of a positive specific inhalation challenge test (van Kampen et al. 2008). A cross-sectional study in bakers did not observe a relationship between occupational sensitization and BHR (Storaas et al. 2007). The authors hypothesized a nonIgE mediated mechanism causing BHR and airway symptoms, based on their former works (Storaas et al. 2005). Concerning our study, we could only test three occupational allergens (wheat flour, rye flour and alpha amylase) and might have missed other relevant ones. As mentioned in the introduction, the use of a large variety of additives has developed during the last decades (Quirce and Diaz-Perales 2013). However, this does not mean there was no effect of occupational sensitization in our study. Indeed, when no exposure variables were present in the model (data not shown), $\mathrm{FEV}_{1}$ was significantly lower among workers with occupational sensitization. The fact that occupational sensitization was only a predictor of a decline in $\mathrm{FEV}_{1}$ when duration of exposure was not included might mean that exposure predicts this decline and sensitization independently but that the latter is not an intermediate in the causal relation between exposure and decline in $\mathrm{FEV}_{1}$. In our study, the prevalence of BHR and symptoms depended on gender and atopic background. Similar to other studies, a higher prevalence of BHR has been observed in women than in men (Brutsche et al. 2006) and in atopics than in non-atopics in a previous study in bakers (Pavlovic et al. 2001).

We identified only few studies exploring the longitudinal decline of $\mathrm{FEV}_{1}$ according to BHR (Abramson et al. 2020; Aldrich et al. 2016; Brutsche et al. 2006). A population-based study (Brutsche et al. 2006) found a relationship between $\mathrm{FEV}_{1}$ and $\mathrm{BHR}$ but did not separate past and concurrent BHR as determinants of $\mathrm{FEV}_{1}$. In new-employed aluminium smelter workers, Abrams on et al. did not find any predictive value of BHR at start of employment concerning the decline of lung function (Abrams on et al. 2020). The median of follow-up was 4 years, which might be too short to be able to observe a detectable functional decline. A study with a longer follow-up in firefighters (Aldrich et al. 2016) found that BHR at 12-year-follow-up was associated with an estimated $15.4 \mathrm{ml} / \mathrm{y}$ greater $\mathrm{FEV}_{1}$ decline than experienced in case of no BHR at follow-up. In our study, the sum of the pre-visit and current BHR effects corresponds to a $180 \mathrm{ml}$ approximated $\mathrm{FEV}_{1}$ loss during 13 years of follow-up, equivalent to a $14 \mathrm{ml} /$ year loss. This is roughly in line with Aldrich et al.'s results (Aldrich et al. 2016), although the context of 
exposure is very different: a massive exposure to inorganic dust and gases for the World Trade Center's collapseexposed firefighters and a chronic exposure to mostly organic dust for the bakers. However, the analyses in firefighters were adjusted on the changes in $\mathrm{FEV}_{1}$ shortly before and after the 9/11/2001, controlling for the effect of this massive exposure. In our study, duration of exposure predicted an additional decrease of near $20 \mathrm{ml} / \mathrm{y}$ in $\mathrm{FEV}_{1}$, independently of the effect of BHR. In Aldrich et al.'s study, the exposure after the World Trade Center's collapse was not taken into account, $76 \%$ of the participants being retired at the end of follow-up (Aldrich et al. 2016).

In our study, we did not observe any dose-response relationships using the quantitative exposure. As the exposure estimation was based on on-going exposure measurements and assessments by industrial hygienists, it is unlikely that it was due to exposure misclassification. A more likely mechanism would be that the high-exposed tasks are only performed by workers, with potentially low sensitization, who withstand these high exposure levels. It could be that workers themselves move to lower-exposed tasks or are more careful, e.g. wearing protective equipment from the appearance of the first work-related symptoms.

Our study has severalstrengths. First, we followed up the population over 13 years with the same study staff using the same protocol. Second, for ten bakers (9\%) only, the reason for drop-out was unknown, and two bakers only dropped out for reasons related to occupational health. This loss to follow-up rate is quite low when compared to studies on apprentices (e.g. $20 \%$ in (Tossa et al. 2010)). This could be due to the fact that all the data collection was done at the workplace. The corresponding drawback was that we had to use an abbreviated version of the MBC test for ethical reason. Subjects lost to follow-up in our study were older, had a shorter duration of employment but had a greater $\mathrm{FEV}_{1}$ than the other bakers (data not shown). However, no statistical difference between them and the other bakers was observed. Third, an attrition bias during the follow-up seems unlikely as no difference in health respiratory status was found at the last visit.

The main weakness of this study is the relatively low sample size, due to small-medium size of the working resources in that activity sector in France. In particular the low number of subjects in the non-exposed might be considered a problem. One must however bear in mind that the results of the present study do not rely on an exposed vs. non-exposed comparison. The non-exposed population is taken as a baseline exposure category in our search of dose-response analyses, in the present paper with duration of exposure and levels of exposure. Thus the inclusion of the non-exposed subjects strengthened the power of detecting such a dose-response. Moreover, the 
inclusion allowed to better take into account confounders. Indeed (data not shown), repeating the analyses without the non-exposed confirmed the effect of the duration of exposure. On the other hand, some confounding factors (pack-years, history of BHR) were no longer significant.

A second possible weakness is the absence of systematic individual exposure measurements which led us to use a semi-quantitative exposure levels in three categories in whose reliability we could trust. The sketchy individual exposure measurements would have been unreliable. Moreover the measurements were obtained using a $1 \mathrm{~L} / \mathrm{min}$ flowrate, which were up to date at the time of the measurements but are lower than the flowrates $(2.5-3 \mathrm{~L} / \mathrm{min})$ which are recommended nowadays. The precision of these suboptimal measurements was however deemed sufficient for the classification in the three exposure categories used.

Finally, a selection effect with an avoidance of the job or an early drop-out from the job of the subjects with atopy cannot be excluded, as discussed above. Despite this healthy worker selection effect, we could observe detrimental effects of exposure on bronchial responsiveness and on $\mathrm{FEV}_{1}$.

\section{CONCLUSION}

In flour-exposed industrial bakers, length of exposure and smoking are long-term determinants of BHR and of the decrease in $\mathrm{FEV}_{1}$. BHR at a preceding visit predicted lower $\mathrm{FEV}_{1}$ even when accounting for the effect of BHR at the current visit. Prevention is still needed for these workers.

\section{Declarations}

FUNDING: The study was not supported by any external specific funding and was entirely funded by INRS.

DATA AVAILABILITY: The data that support the findings of this study are not available for legal reas ons. Access to research data must be authorized by the French data protection agency (Commission nationale de l'informatique et des libertés) before the study begins.

CONFLICT OF INTEREST: The authors have no conflicts of interest to declare.

CODE AVAILABILITY: Not applicable. 
ETHICS APPROVAL: The study was approved by the relevant French ethical committee (Comité consultatif de protection des personnes dans la recherche biomédicale de Lorraine) and the French data protection agency (Commission nationale de l'informatique et des libertés) and has therefore been performed in accordance with the ethical standards laid down in the 1964 Declaration of Helsinki and its later amendments. All the subjects gave free written and informed consent to participate.

\section{Figure caption}

Fig 1: Flow chart of the study. *drop-out unrelated to health 


\section{REFERENCES}

Abramson MJ, Gwini SM, de Klerk NH, Del Monaco A, DennekampM, Fritschi L, Dimitriadis C, Mohebbi M, Musk AWB, Sim MR (2020) Predictive value of non-specific bronchial challenge testing for respiratory symptoms and lung function in aluminium smelter workers Occup Environ Med 77:535-539 doi:10.1136/oemed-2019-106344

Acouetey DS, Zmirou-Navier D, Avogbe PH, Tossa P, Remen T, Barbaud A, Cornejo-Garcia JA, Blanca M, Bohadana A, Paris C, Gueant JL, Gueant-Rodriguez RM (2013) Genetic predictors of inflammation in the risk of occupational asthma in young apprentices Annals of allergy, asthma \& immunology : official publication of the American College of Allergy, Asthma, \& Immunology 110:423-428 e425 doi:10.1016/j.anai.2013.04.005

Aldrich TK, Weakley J, Dhar S, Hall CB, Crosse T, Banauch GI, Weiden MD, Izbicki G, Cohen HW, Gupta A, King C, Christodoulou V, Webber MP, Zeig-Owens R, Moir W, Nolan A, Kelly KJ, Prezant DJ (2016) Bronchial Reactivity and Lung Function After World Trade Center Exposure Chest 150:1333-1340 doi:10.1016/j.chest.2016.07.005

Amaral AFS, Newson RB, Abramson MJ, Anto JM, Bono R, Corsico AG, de Marco R, Demoly P, Forsberg B, Gislason T, Heinrich J, Huerta I, Janson C, Jogi R, Kim JL, Maldonado J, Martinez-Moratalla Rovira J, Neukirch C, Nowak D, Pin I, Probst-Hensch N, Raherison-Semjen C, Svanes C, Urrutia Landa I, van Ree R, Versteeg SA, Weyler J, Zock JP, Burney PGJ, Jarvis DL (2016) Changes in IgE sensitization and total IgE levels over 20 years of follow-up J Allergy Clin Immunol 137:17881795 e1789 doi:10.1016/j.jaci.2015.09.037

Bagheri HM, Krozhdeh J, Khanjani N, Zamani A, Ranjbar M, Mohammadian M (2013) Relationship between lung function and flour dust in flour factory workers J Community Health Res 2:138146

Bohadana AB, Massin N, Wild P, Kolopp MN, Toamain JP (1994) Respiratory symptoms and airway responsiveness in apparently healthy workers exposed to flour dust Eur Respir J 7:1070-1076 doi:10.1183/09031936.94.07061070

Borak J, Lefkowitz RY (2016) Bronchial hyperresponsiveness Occup Med (Lond) 66:95-105 doi:10.1093/occmed/kqv158

Brutsche MH, Downs SH, Schindler C, Gerbase MW, Schwartz J, Frey M, Russi EW, Ackermann-Liebrich $U$, Leuenberger $P$, Team S (2006) Bronchial hyperresponsiveness and the development of asthma and COPD in asymptomatic individuals: SAPALDIA cohort study Thorax 61:671-677 doi:10.1136/thx.2005.052241

Butland BK, Ghosh R, Strachan DP, Cullinan P, Jarvis D (2011) Job choice and the influence of prior asthma and hay fever Occup Environ Med 68:494-501 doi:10.1136/oem.2010.058065

Cullinan P, Cook A, Nieuwenhuijsen MJ, Sandiford C, Tee RD, Venables KM, McDonald JC, Newman Taylor AJ (2001) Allergen and dust exposure as determinants of work-related symptoms and sensitization in a cohort of flour-exposed workers; a case-control analysis Ann Occup Hyg 45:97-103

de Meer G, Postma DS, Heederik D (2003) Bronchial responsiveness to adenosine-5'-monophosphate and methacholine as predictors for nasal symptoms due to newly introduced allerge ns. A follow-up study among laboratory animal workers and bakery apprentices Clin Exp Allergy 33:789-794

De Zotti R, Bovenzi M (2000) Prospective study of work related respiratory symptoms in trainee bakers Occup Environ Med 57:58-61

Demange V, Zmirou-Navier D, Bohadana A, Wild P (2018) Do airway inflammation and airway responsiveness markers at the start of apprenticeship predict their evolution during initial training? A longitudinal study among apprentice bakers, pastry makers and hairdressers BMC pulmonary medicine 18:113 doi:10.1186/s12890-018-0674-9 
Demeke D, Haile DW (2018) Assessment of Respiratory Symptoms and Pulmonary Function Status among Workers of Flour Mills in Addis Ababa, Ethiopia: Comparative Cross-Sectional Study Pulm Med 2018:9521297 doi:10.1155/2018/9521297

Droste J, Vermeire P, Van Sprundel M, Bulat P, Braeckman L, Myny K, Vanhoorne M (2005) Occupational exposure among bakery workers: impact on the occurrence of work-related symptoms as compared with allergic characteristics J Occup Envi ron Med 47:458-465

Fahim AE, El-Prince M (2013) Pulmonary function impairment and airway allergy among workers in traditional bakeries Int J Occup Med Environ Health 26:214-219 doi:10.2478/s13382-0130082-6

Florentin A, Acouetey DS, Remen T, Penven E, Thaon I, Zmirou-Navier D, Paris C (2014) Exhaled nitric oxide and screening for occupational asthma in two at-risk sectors: bakery and hairdressing Int J Tuberc Lung Dis 18:744-750 doi:10.5588/ijtld.13.0641

Gardner RM (1979) Report of Snowbird workshop on standardization of spirometry Am Rev Respir Dis 119:831-838

Gautrin D, Ghezzo H, Infante-Rivard C, Malo JL (2000) Incidence and determinants of IgE-mediated sensitization in apprentices. A prospective study Am J Respir Crit Care Med 162:1222-1228 doi:10.1164/ajrccm.162.4.2001023

Harris-Roberts J, Robinson E, Waterhouse JC, Billings CG, Proctor AR, Stocks-Greaves M, Rahman S, Evans G, Garrod A, Curran AD, Fishwick D (2009) Sensitization to wheat flour and enzymes and associated respiratory symptoms in British bakers Am J Ind Med 52:133-140 doi:10.1002/ajim.20639

Hoppin JA, Jaramillo R, Salo P, Sandler DP, London SJ, Zeldin DC (2011) Questionnaire predictors of atopy in a US population sample: findings from the National Health and Nutrition Examination Survey, 2005-2006 Am J Epidemiol 173:544-552 doi:10.1093/aje/kwq392

Hur GY, Koh DH, Kim HA, Park HJ, Ye YM, Kim KS, Park HS (2008) Prevalence of work-related symptoms and serum-specific antibodies to wheat flour in exposed workers in the bakery industry Respir Med 102:548-555 doi:10.1016/j.rmed.2007.11.015

Iwatsubo Y, Bénézet L, Bonnet N, Garras L, Ameille J, Dalphin JC, De Blay F, Garnier R, L'Huillier JP, Pairon JC, Pauli G (2016) Observatoire National des Asthmes Professionnels II. Bilan de la phase pilote et perspectives pour la surveillance des asthmes en lien avec le travail. Santé Publique France, Saint Maurice

Iwatsubo Y, Matrat M, Brochard P, Ameille J, Choudat D, Conso F, Coulondre D, Garnier R, Hubert C, Lauzier F, Romano MC, Pairon JC (2003) Healthy worker effect and changes in respiratory symptoms and lung function in hairdressing apprentices Occup Environ Med 60:831-840 doi:10.1136/oem.60.11.831

Jacobs JH, Meijster T, Meijer E, Suarthana E, Heederik D (2008) Wheat allergen exposure and the prevalence of work-related sensitization and allergy in bakery workers Allergy 63:1597-1604 doi:10.1111/j.1398-9995.2008.01698.x

Jeebhay MF, Moscato G, Bang BE, Folletti I, Lipinska-Ojrzanowska A, Lopata AL, Pala G, Quirce S, Raulf M, Sastre J, Swoboda I, Walusiak-Skorupa J, Siracusa A (2019) Food processing and occupational respiratory allergy- An EAACl position paper Allergy 74:1852-1871 doi:10.1111/all.13807

Johansson SG, Hourihane JO, Bousquet J, Bruijnzeel-Koomen C, Dreborg S, Haahtela T, Kowalski ML, Mygind N, Ring J, van Cauwenberge P, van Hage-Hamsten M, Wuthrich B, force Ent (2001) A revised nomenclature for allergy. An EAACl position statement from the EAACI nomenclature task force Allergy 56:813-824 doi:10.1034/j.1398-9995.2001.t01-1-00001.x

Kim MH, Jung JW, Kang HR (2013) The usefulness of job relocation and serum eosinophil cationic protein in baker's asthma Int Arch Allergy Immunol 161:252-257 doi:10.1159/000346541

Lagiso ZA, Mekonnen WT, Abaya SW, Takele AK, Workneh HM (2020) Chronic respiratory symptoms, lung function and associated factors among flour mill factory workers in Hawassa city, 
southern Ethiopia: "comparative cross-sectional study" BMC Public Health 20:909 doi:10.1186/s12889-020-08950-9

Lipinska-Ojrzanowska A, Nowakowska-Swirta E, Wiszniewska M, Walusiak-Skorupa J (2020) Bronchial Response to High and Low Molecular Weight Occupational Inhalant Allergens Allergy Asthma Immunol Res 12:164-170 doi:10.4168/aair.2020.12.1.164

Malo JL, Tarlo SM, Sastre J, Martin J, Jeebhay MF, Le Moual N, Heederik D, Platts-Mills T, Blanc PD, Vandenplas O, Moscato G, de Blay F, Cartier A, Workplace ATSahcoAit (2015) An official American Thoracic Society Workshop Report: presentations and discussion of the fifth Jack Pepys Workshop on Asthma in the Workplace. Comparison sbetween asthma in the workplace and non-work-related asthma Ann Am Thorac Soc 12:S99-S110 doi:10.1513/AnnalsATS.201505-281ST

Mbatchou Ngahane BH, Afane Ze E, Nde F, Ngomo E, Mapoure NjankouoY, Njock LR (2014) Prevalence and risk factors for allergic rhinitis in bakers in Douala, Cameroon BMJ Open 4:e005329 doi:10.1136/bmjopen-2014-005329

Minette A (1989) Questionnaire of the European Community for Coal and Steel (ECSC) on respiratory symptoms. 1987--updating of the 1962 and 1967 questionnaires for studying chronic bronchitis and emphysema Eur Respir J 2:165-177

Minov JB, Karadzinska-Bislimovska JD, Vasilevska KV, Stoleski SB, Mijakoski DG (2013) Exercise-related respiratory symptoms and exercise-induced bronchoconstriction in industrial bakers Arch Environ Occup Health 68:235-242 doi:10.1080/19338244.2012.701249

Moghaddasi Y, Mirmohammadi S, Ahmad A, Nejad SE, Yazdani J (2014) Health-risk assessment of workers exposed to flour dust: a cross-sectional study of random samples of bakeries workers Atmos Pollut Res 5:113-118 doi:10.5094/APR.2014.014

Mohammadien HA, Hussein MT, R.T. E-S (2013) Effects of exposure to flour dust on respiratory symptoms and pulmonary function of mill workers Egypt J Chest Dis Tuberc 62:745-753 doi:10.1016/j.ejcdt.2013.09.007

Monso E, Malo JL, Infante-Rivard C, Ghezzo H, Magnan M, L'Archeveque J, Trudeau C, Gautrin D (2000) Individual characteristics and quitting in apprentices exposed to high-molecular-weight agents Am J Respir Crit Care Med 161:1508-1512 doi:10.1164/ajrccm.161.5.9906113

Olivieri M, Biscardo CA, Palazzo P, Pahr S, Malerba G, Ferrara R, Zennaro D, Zanoni G, Xumerle L, Valenta R, Mari A (2013) Wheat IgE profiling and wheat IgE levels in bakers with allergic occupational phenotypes Occup Environ Med 70:617-622 doi:10.1136/oemed-2012-101112

Page EH, Dowell CH, Mueller CA, Biagini RE, Heederik D (2010) Exposure to flour dust and sensitization among bakery employees Am J Ind Med 53:1225-1232 doi:10.1002/ajim.20893

Pavlovic M, Spasojevic M, Tasic Z, Tacevic S (2001) Bronchial hyperactivity in bakers and its relation to atopy and skin reactivity Sci Total Environ 270:71-75

Quanjer PH, Tammeling GJ, Cotes JE, Pedersen OF, Peslin R, Yernault JC (1993) Lung volumes and forced ventilatory flows. Report Working Party Standardization of Lung Function Tests, European Community for Steel and Coal. Official Statement of the European Respiratory Society Eur Respir J Suppl 16:5-40

Quirce S, Diaz-Perales A (2013) Diagnosis and management of grain-induced asthma Allergy Asthma Immunol Res 5:348-356 doi:10.4168/aair.2013.5.6.348

Radon K, Nowak D, Vogelberg C, Rueff F (2016) Career Advice for Young Allergy Patients Dtsch Arztebl Int 113:519-524 doi:10.3238/arztebl.2016.0519

Remen T, Acouetey DS, Paris C, Hannhart B, Poussel M, Chenuel B, Barbaud A, Zmirou-Navier D (2013) Early incidence of occupational asthma is not accelerated by atopy in the bakery/pastry and hairdressing sectors Int J Tuberc Lung Dis 17:973-981 doi:10.5588/ijtld.12.0864

Said AM, AbdelFattah EB, Almawardi A-A (2017) Effects on respiratory system due to exposure to wheat flour Egypt J Chest Dis Tuberc 66:537-548 
Skjold T, Dahl R, Juhl B, Sigsgaard T (2008) The incidence of respiratory symptoms and sensitisation in baker apprentices Eur Respir J 32:452-459 doi:10.1183/09031936.00108207

Storaas T, Irgens A, Florvaag E, Steinsvag SK, Ardal L, Do TV, Greiff L, Aasen TB (2007) Bronchial responsiveness in bakery workers: relation to airway symptoms, IgE sensitization, nasal indices of inflammation, flour dust exposure and smoking Clin Physiol Funct Imaging 27:327-334 doi:10.1111/j.1475-097X.2007.00755.x

Storaas T, Steinsvag SK, Florvaag E, Irgens A, Aasen TB (2005) Occupational rhinitis: diagnostic criteria, relation to lower airway symptoms and IgE sensitization in bakery workers Acta Otolaryngol 125:1211-1217 doi:10.1080/00016480510044205

Tossa P, Paris C, Zmirou-Navier D, Demange V, Acouetey DS, Michaely JP, Bohadana A (2010) Increase in exhaled nitric oxide is associated with bronchial hyperresponsiveness among apprentices Am J Respir Crit Care Med 182:738-744 doi:10.1164/rccm.200903-04150C

van Kampen V, Rabstein S, Sander I, Merget R, Bruning T, Broding HC, Keller C, Musken H, Overlack A, Schultze-Werninghaus G, Walusiak J, Raulf-Heimsoth M (2008) Prediction of challenge test results by flour-specific IgE and skin prick test in symptomatic bakers Allergy 63:897-902 doi:10.1111/j.1398-9995.2008.01646.x

Walusiak J, Palczynski C, Hanke W, Wittczak T, Krakowiak A, Gorski P (2002) The risk factors of occupational hypersensitivity in apprentice bakers -- the predictive value of atopy markers Int Arch Occup Environ Health 75 Suppl:S117-121 doi:10.1007/s00420-002-0358-9

Warm K, Backman H, Lindberg A, Lundback B, Ronmark E (2012) Low incidence and high remission of allergic sensitization among adults J Allergy Clin Immunol 129:136-142 doi:10.1016/j.jaci.2011.08.033

Wild P, Mevel H, Penven E, Zmirou-Navier D, Barbaud A, Bohadana A, Paris C (2017) FeNO levels increase with degree of sensitisation in apprentices at risk of occupational asthma Int J Tuberc Lung Dis 21:1194-1200 doi:10.5588/ijtld.16.0758

Zamani A, Khanjani N, Bagheri HM, Ranjbar MH, Miri R (2019) The effect of chronic exposure to flour dust on pulmonary functions Int J Occup Saf Ergon:1-7 doi:10.1080/10803548.2019.1582853 